\title{
PERB ANDINGAN METODE OPTIMASI UNTUK PENGELOMPOKAN PROVINSI BERDASARKAN SEKTOR PERIKANAN DI INDONESIA (Studi Kasus Dinas Kelautan dan Perikanan Indonesia)
}

\author{
Edy Sulistiyawan $^{1 *}$, Alfisyahrina Hapsery ${ }^{2}$, Lucky Junita Ayu Arifahanum ${ }^{3}$ \\ ${ }^{1}$ Program Studi Managemen, Fakultas Ekonomi dan Bisnis, Universitas PGRI Adi Buana Surabaya \\ ${ }^{2,3}$ Program Studi Statistika, Fakultas Sains dan Teknologi, Universitas PGRI Adi Buana Surabaya \\ *email: edy.sulistiyawan@ gmail.com
}

\begin{abstract}
The fisheries sector has an important role in supporting the food security chain, where the world's protein needs can be met by fisheries resources, both from capture fisheries and aquaculture. There are several fisheries sectors including fishing companies, capture fisheries production, number of ships, types and size of cultivated land. Therefore a statistical analysis is needed to increase the potential of fisheries in Indonesia. Data on the fisheries sector used in this study from the Indonesian Central Statistics Agency in 2018, which included the 2016 fisheries sector with 34 observation units in Indonesia. By using cluster analysis $K$-Means aims to group provinces in Indonesia based on the fisheries sector so that several groups are formed which will show the characteristics of each group. There are three determinations of the optimum number of clusters, namely the Elbow method, Silhouette method, and GAP Statistics. The results showed that optimum clusters were formed in 2 clusters, with the best Elbow and Silhouettemethods. Where the first cluster is a region that shows a low value of the fisheries sector consisting of 30 provinces this is due to inadequate infrastructure and use that is not optimal while cluster 2 regions that have great potential in the Indonesian fisheries sector in 2016 as many as 4 provinces namely West Java, Java Central, East Java, and South Sulawesi as dominating capture fisheries production and aquaculture.
\end{abstract}

Keywords: Fisheries Sector, K-Means Cluster Analysis, Elbow Method, Silhoutte Method and GAP Statistics.

\section{PENDAHULUAN}

Negara kepulauan yang memiliki berbagai potensi laut dan dikenal beranekaragam yaitu Indonesia. Potensi tersebut tersebar sepanjang kurang lebih 5,8 juta $\mathrm{km}$ zona maritim. Pembangunana ekonomi di Indonesia sangat berpotensi dengan didukung perikanan, terutama peluang lapangan pekerjaan. Kelautan sangat berperan penting untuk pemerataan pendapatan serta peningkatan taraf hidup nelayan kecil, dan para pengusaha dibidang perikanan (Kementerian Kelautan dan Perikanan, 2013).

Meningkatnya produksi hasil perikanan di Indonesia berkaitan dengan kondisi dan letak suatu daerah. Sebagaimana setiap wilayah memiliki kawasan penangkapan dengan karakteristik yang berbeda-beda. Untuk mengetahui karakteristik suatu kelompok pada sektor perikanan berdasarkan data masing-masing daerah dapat dianalisis menggunakan Ilmu statistika. Analisa multivariat yang dapat memahami, menjelaskan dan mengelompokkan seperangkat variabel adalah analisis cluster. Pada analisis ini, pengelompokan objek terjadi berdasarkan kemiripan antar objek (Supranto,2004). Pengukuran kesamaan dari seluruh objek dapat diukur dengan ukuran kedekatan antar objek yang terdapat kedekatan ataupun tidak. Terdapat tiga metode dalam menentukan jumlah cluster yang optimum yaitu metode Elbow, metode Silhouette, dan GAP Statistic. Penentuan cluster optimum pada metode Elbow dapat dilihat dari nilai Sum Square Error (SSE), dimana jika nilai SSE semakin kecil maka nilai cluster tersebut terbaik. Berbeda dengan metode Silhouette, nilai koefisien Silhouette biasanya di antara rentang -1 sampai dengan 1. Nilai koefisien Silhouette yang mendekati 1 adalah yang lebih baik. Sedangkan GAP Statistic dikatakan cluster optimum jika nilai GAP Statistic mengalami kenaikan yang paling tinggi. 
Pada penelitian sebelumnya yang berkaitan dengan analisis cluster adalah penelitian Prayoga \& Ismaini Zain (2015) yang berjudul "Analisis faktor dan pengelompokkan kecamatan berdasarkan indikator mutu pendidikan jenjang pendidikan dasar di kabupaten Sidoarjo", tebentuk 3 kelompok pada jenjang SD dan 2 kelompok pada jenjang SMP dari 18 kecamatan Sidoarjo. Dengan adanya pemaparan diatas sehingga digunakan Analisis Cluster Non Hirarki untuk dapat pengelompokan serta membuat visualisasi pemetaan provinsi di Indonesia berdasarkan sektor perikanan sehingga terbentuk beberapa kelompok yang akan menunjukkan karakteristik anggota-anggota cluster yang terbentuk.

Berdasarkan penjelasan tersebut akan dilakukan pengelompokkan sektor perikananan di Indonesia berdasarkan faktor-faktor yang mempengaruhinya antara lain jumlah rumah tangga/perusahaan tangkap, produksi perikanan tangkap, jumlah perahu/kapal, jumlah rumah tangga perikanan budidaya, jenis budidaya perikanan, produksi perikanan budidaya, luas area tambak usaha budidaya perikanan tambak, dan luas area kolam usaha budidaya perikanan. Dengan menggunakan analisis cluster untuk mengetahui karakteristik suatu anggota cluster yang terbentuk. Serta mengetahui metode mana yang terbaik dalam menentukan jumlah cluster pada sektor perikanan Indonesia. Hal ini yang melatarbelakang penulis mengangkat sebuah penelitian skripsi yang berjudul "Perbandingan Metode Optimasi untuk Pengelompokan Provinsi Berdasarkan Sektor Perikanan di Indonesia".

\section{TINJAUAN PUSTAKA}

\subsection{Analisis dan Asumsi Cluster}

Analisis multivariate yang mengelompokkan objek dikenal dengan sebutan cluster. Konsep dari metode ini adalah mengelompokkan objek kedalam kelompok berdasrkan homogenitas dari objek tersebut (Supranto,2004). Mengukur kedekatan diantara banyak objek dilakukan dengan perhitungan jarak menggunakan Euclidean (Johnson \& Wichern, 1982). Analisis cluster dibagi menjadi dua metode yaitu metode hirarki dan metode non hirarki. Analisis cluster dengan menggunakan metode non hirarki adalah metode pengelompokan dengan menentukan banyak kelas terlebih dahulu. K-Means merupakan salah satu metode data clustering non hierarki yang berusaha mempartisi data yang ada ke dalam bentuk satu atau lebih cluster/kelompok.

\subsection{K-Me ans Cluster}

Permartisian suatu objek pada suatu k kelompok dapat dilakukan dengan analisis $K$ Means. Setiap objek pengamatan akan mengelompok berdasarkan nilai rata-rata terdekat, dengan bantuan iterasi sesuai dengan algoritma untuk mendapatkan pusat kelompok (Prasetyo, 2012).

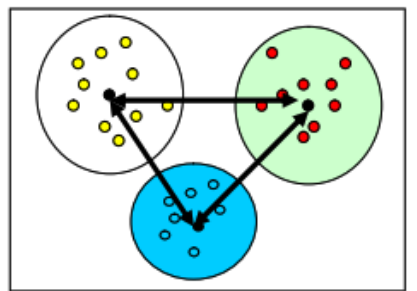

Gambar 2.1 Cluster K-Means

$K$-Means salah satu metode pengelompokan data non hirarki yang berusaha mempartisi data yang ada ke dalam bentuk dua atau lebih kelompok. Metode ini mempartisi data untuk meminimalis ir varians kedalam kelompok sehingga data berkarakteristik sama di masukkan kedalam kelompok yang lain (Agusta, 2007). 


\subsection{Optimasi Jumlah Cluster}

Bagian ini hanya berisikan dasar teori yang sangat dibutuhkan, yang sangat mendukung metode penelitian dan pembahasan. Teori yang bersifat umum tidak perlu dituliskan

\section{a. Metode Elbow}

Bagian ini hanya berisikan dasar teori yang sangat dibutuhkan, yang sangat mendukung metode penelitian dan pembahasan. Teori yang Metode Elbow merupakan metode untuk menghasilkan informasi dalam menetukan jumlah cluster terbaik. Jika nilai cluster pertama dengan cluster kedua memberikan sudut dalam grafik atau nilainya mengalami penurunan paling besar maka nilai cluster tersebut terbaik. Untuk mendapatkan perbandingannya adalah dengan menghitung SSE (Sum of Square Error) dari masing-masing nilai cluster. Berikut rumus SSE pada K-means.

$$
S S E=\sum_{K=1}^{K} \sum_{x_{i} \in S_{K}}\left\|X_{i}-C_{k}\right\|_{2}^{2}
$$

Dimana k adalah Cluster, $X_{i}$ adalah data ke-i dalam cluster $\mathrm{x}, C_{k}$ adalah nilai rata-rata $\mathrm{k}$ cluster.

\section{b. Metode Silhouette}

Silhouette Coefficient (SC) merupakan metode yang digunakan untuk memvalidasi pengelompokan. Silhouette gabungan dari cohesion dan separation (Tan et all. 2006). Cohesion dan separation digunakan untuk mengukur akurasi pengelompokan berdasarkan kesamaan atau ketidaksamaan antar cluster. Cohesion digunakan untuk mengukur kedekatan data yang berada pada satu cluster sedangkan separation digunakan untuk mengukur kedekatan antar cluster yang terbentuk (Ramadhan, 2010). Nilai koefisien Silhouette biasanya di antara rentang -1 sampai dengan 1. Nilai koefisien Silhouette yang mendekati 1 adalah yang lebih baik. Hitung rata-rata jarak dari suatu objek misalkan i dengan semua objek lain yang berada dalam satu claster.

$$
a(i)=\frac{1}{|A|} \sum j \in_{A, j \neq i} C d(i, j)
$$

$\mathrm{j}$ adalah Objek lain dalam satu claster, sedangkan d(i,j) adalah jarak antar onjek i dengn j. Hitung rata-rata dari objek i tersebut dengan semua objek di cluster lain, dan diambil nilai terkecilnya.

$$
d(i, C)=\frac{1}{|A|} \sum j \in C d(i, j)
$$

$\mathrm{d}(\mathrm{i}, \mathrm{C})$ adalah jarak rata-rata objek i dengan semua objek pada cluster lain atau $\mathrm{C}$ dimana $\mathrm{A} \neq \mathrm{C}$, sedangkan $\mathrm{b}(\mathrm{i})$ adalah min $\mathrm{C} \neq \mathrm{A} \mathrm{d}(\mathrm{i}, \mathrm{C})$. Nilai koefisien Silhouette nya dihitung menggunakan persamaan ini.

\section{c. GAP Statistic}

$$
s(i)=\frac{b(i)-a(i)}{\max (a(i), b(i)},
$$

GAP Statistic digunakan ketika akan membentuk cluster agar lebih hasil dapat konstan jika dibandingkan lainnya. Jarak objek berpasangan dalam cluster dihitung dengan rumus:

$$
D_{r}=\sum_{i, i^{\prime} \in C_{r}} d i i^{\prime}
$$

d merupakan jarak euclidean kuadrat. Untuk menghitung jumlah kuadrat pada cluster menggunakan rumus

$$
W_{k}=\sum_{r=1}^{k} \frac{1}{2 n_{r}} D_{r},
$$


nilai GAP didapatkan dengan mengestimasi jumlah cluster optimum pendekatan standardisasi $W_{k}$

$$
\operatorname{Gap}_{n}(k)=E_{n}^{*}\left\{\log \left(W_{k}\right)\right\}-\log \left(W_{k}\right)
$$

dimana $E_{n}^{*}$ adalah nilai ekspektasi dari distribusi jumlah sampel. Kriteria banyak cluster optimum diberikan oleh nilai GAP Statistic (k) yang paling tinggi, atau yang pertama kali mengindikasi kenaikan GAP yang minimum jika gap selalu naik (Tibshirani, dkk. 2001).

\section{METODE PENELITIAN}

\subsection{Sumber Data dan Variabel}

Data yang digunakan pada penelitian ini diperoleh dari Badan Pusat Statistik Indonesia tahun 2018. Data yang digunakan adalah data sektor perikanan di Indonesia tahun 2016 yang terdiri dari 34 provinsi. Penelitian ini menggunakan 10 variabel sektor perikanan Indonesia tahun 2016 seperti pada Tabel 1 berikut.

Tabel 1. Variabel Penelitian Sektor Perikanan Indonesia Tahun 2016

\begin{tabular}{|c|c|c|}
\hline & Variabel Penelitian & Definisi Operasional \\
\hline$\overline{\mathbf{X}_{1}}$ & $\begin{array}{l}\text { Jumlah Rumah Tangga / } \\
\text { Perusahaan Tangkap }\end{array}$ & $\begin{array}{l}\text { Jumlah/total rumah tangga yang melakukan } \\
\text { penangkapan ikan/binatang air lainya/tanaman air. }\end{array}$ \\
\hline $\mathbf{X}_{2}$ & Produksi Perikanan Tangkap & Hasil penangkapan ikan laut yang ada di provinsi(ton). \\
\hline $\mathbf{X}_{3}$ & Jumlah Perahu/Kapal & Jumlah kapal motor yang ada di provinsi. \\
\hline $\mathbf{X}_{4}$ & $\begin{array}{l}\text { Jumlah Rumah Tangga Perikanan } \\
\text { Budidaya tambak }\end{array}$ & $\begin{array}{l}\text { Jumlah/total rumah tang ga yang melakukan kegiatan } \\
\text { budidaya ikan/binatang air lainya/tanaman air dengan } \\
\text { media tambak. }\end{array}$ \\
\hline $\mathbf{X}_{5}$ & $\begin{array}{l}\text { Jumlah Rumah Tangga Perikanan } \\
\text { Budidaya kolam }\end{array}$ & $\begin{array}{l}\text { Jumlah/total rumah tang ga yang melakukan kegiatan } \\
\text { budidaya ikan/binatang air lainya/tanaman air dengan } \\
\text { media kolam. }\end{array}$ \\
\hline $\mathbf{X}_{6}$ & Jenis Budidaya Perikanan & $\begin{array}{l}\text { Luas lahan jenis budidayayang digunakan dengan } \\
\text { satuanha }\end{array}$ \\
\hline $\mathbf{X}_{7}$ & $\begin{array}{l}\text { Produksi Perikanan Budidaya } \\
\text { Tambak }\end{array}$ & $\begin{array}{l}\text { Hasil penangkapan budidaya ikan tambakyang ada di } \\
\text { provinsi(ton). }\end{array}$ \\
\hline $\mathbf{X}_{8}$ & $\begin{array}{l}\text { Produksi Perikanan Budidaya } \\
\text { Kolam }\end{array}$ & $\begin{array}{l}\text { Hasil penangkapan budidaya ikan kolamyang adadi } \\
\text { provinsi(ton). }\end{array}$ \\
\hline $\mathbf{X}_{\mathbf{9}}$ & $\begin{array}{l}\text { Luas Area Tambak Usaha } \\
\text { Budidaya Perikanan Tambak }\end{array}$ & $\begin{array}{l}\text { Luas lahan tambak yang digunakan dalamkegiatan } \\
\text { budidaya dengan satuan ha. }\end{array}$ \\
\hline $\mathbf{X}_{10}$ & $\begin{array}{l}\text { Luas Area KolamUsaha Budidaya } \\
\text { Perikanan }\end{array}$ & $\begin{array}{l}\text { Luas lahan kolamyang digunakan dalam kegiatan } \\
\text { budidaya dengan satuan ha. }\end{array}$ \\
\hline
\end{tabular}

\subsection{Metode Analisis Data}

Langkah-langkah analisis pada penelitian ini dapat dipaparkan sebagai berikut :

1. Melakukan analisis statistika deskriptif untuk mengkaji karakteristik sektor perikanan pada tahun 2016 dengan menggunakan penyajian tabel.

2. Melakukan standarisasi data dengan menggunakan Z-Score.

3. Menentukan cluster optimum terbaik dengan menggunakan metode Elbow, metode Silhouette, dan GAP statistic.

4. Menentukan centroid dari data pada setiap cluster

5. Menentukan jarak pada setiap objek dengan setiap centroid untuk menghitung jarak disetiap objek dengan centroid berdasrkan Euclidean Distance

6. Mengklasifikasikan setiap data berdasarkan kedekatan dengan centroid (jarakminimum) 
7. Membagi wilayah sesuai dengan jumlah cluster yang terbentuk

8. Mengintepretasikan karakteristik anggota cluster yang terbentuk

9. Kesimpulan

\section{HASIL DAN PEMBAHASAN}

Analisis dan pembahsan pada sektor perikanan indonesia diawali dengan melihat karakteristik data sektor perikanan, Pengujian asumsi analisis cluster, Pengelompokan wilayah berdasarkan K-means Cluster, dan Visualisasi data dari hasil pengelompokan wilayah berdasarkan sektor perikanan di Indonsia.

\subsection{Karakteristik Sektor Perikanan}

Karakteristik sektor perikanan Indonesia pada tahun 2016 dapat dilihat pada diagram batang pada Gambar 1 berikut.
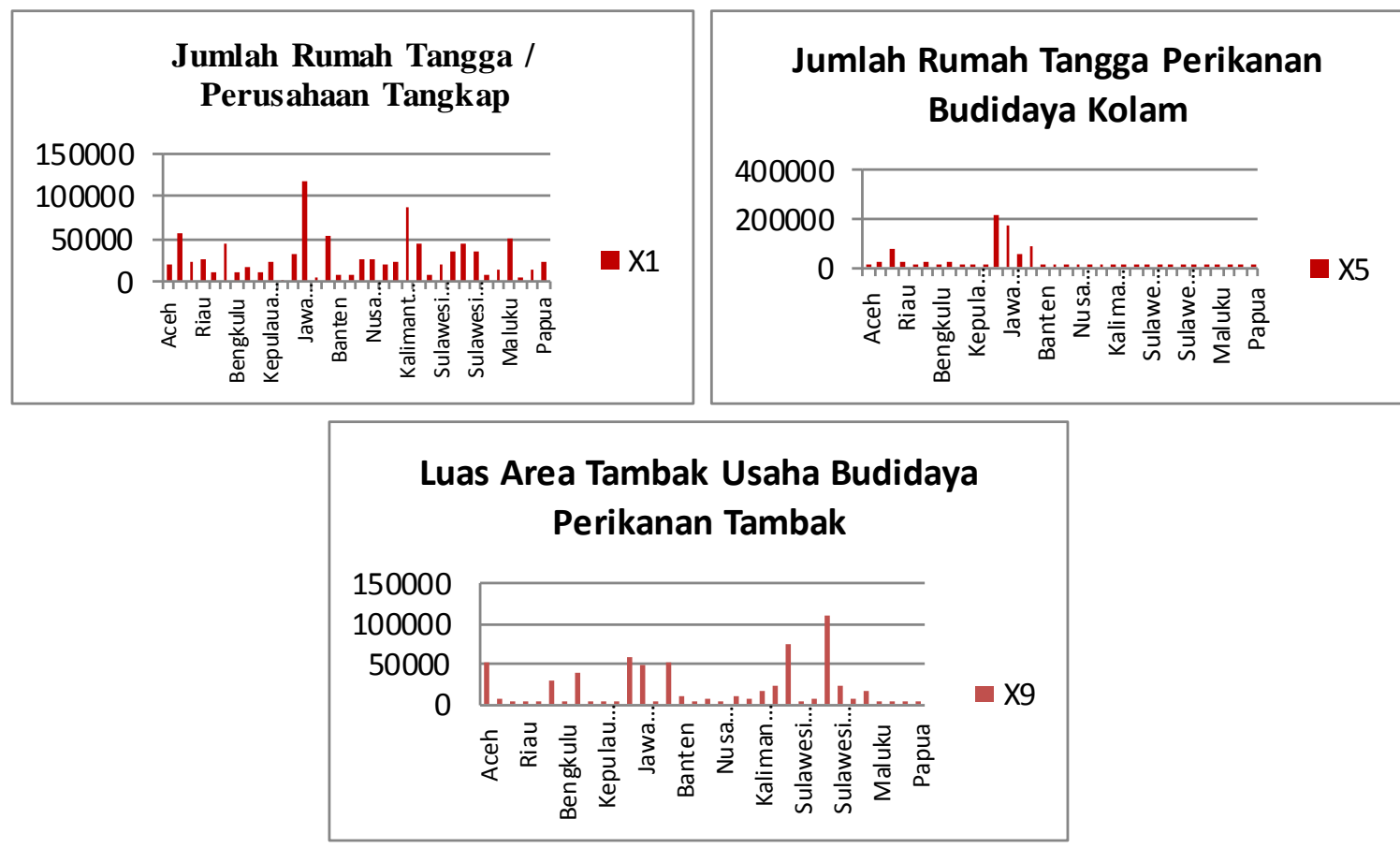

Gambar 1. Diagram Batang (a) Jumlah Rumah Perusahaan Tangkap, (b) Jumlah RT Perikanan Budidaya Kolam, (c) Luas Area Tambah Usaha Budidaya Perikanan Tambak.

Gambar 1 menjelaskan karakteristik dari beberapa variabel. Jumlah rumah tangga (RT)/perusahaan tangkap di Indonesia pada provinsi Jawa Tengah mencapai 118.939 RT yang merupakan jumlah tertinggi di Indonesia pada tahun 2016. Rata-rata jumlah rumah tangga (RT)/perusahaan tangkap sebesar 28.413. Jumlah rumah tangga perikanan budidaya kolam yang tertinggi di Indonesia pada tahun 2016 terjadi pada provinsi Jawa Barat sebesar 218.335 rumah tangga (RT). Sedangkan untuk jumlah rumah tangga perikanana budidaya kolam terendah terjadi pada provinsi Maluku mencapai 179 RT. Indonesia memiliki ratarata untuk jumlah rumah tangga perikanana budidaya tambak sebesar 26.215 RT. Luas area tambak usaha budidaya perikanan di Indonesia pada tahun 2016 memiliki luas terbesar pada provinsi Sulawesi Selatan mencapai 111.039 ha. Sedangkan Provinsi Sumatra Barat memiliki luas area tambak usaha budidaya perikanan terendah mencapai 17 ha. Rata-rata luas area tambak usaha budidaya perikanan di Indonesia pada tahun 2016 mencapai 17.821 ha. 


\subsection{Pengujian Asumsi Analisis Cluster}

Beberapa tahapan sebelum melakukan analisis cluster K-Means yaitu uji asumsi dan penetuan jumlah cluster optimum uji asumsi kecukupan data dan multikolinieritas sebagai berikut.

\section{a. Uji Asumsi Kecukupan Data}

Pengujian kecukupan data dapat dilihat dari hasil pengujian dengan Kaiser Mayer Olkin (KMO). Dimana pendugaan awal adalah jumlah sampel tidak memenuhi kreteria untuk analisa lebih lanjut.

Tabel 3 Uji Kaiser Mayer Olkin

\begin{tabular}{ll}
\hline Keteragan & Nilai \\
\hline KMO Measure of Sampling Adequacy & 0.72 \\
\hline Bartlett's Test & 289.33 \\
\hline \hline
\end{tabular}

Tabel 3 memberikan informasi nilai KMO sebesar 0,72. Hal tersebut menunjukkan bahwa nilai 0.72 lebih besar dari 0.5 , yang berarti tolak $\mathrm{H}_{0}$ sehingga kesimpulan yang diambil adalah sampel telah memenuhi untuk dilakukan analisis.

\section{b. Uji Multikolinie ritas}

multikolinieritas dapat diketahui dari nilai koefisien pada pengujian korelasi sederhana (Corelation Pearson). Hasil analisis menunujukkan adanya korelasi antar variabel independent yang tertinggi sebesar 0.898 yang didapatkan dari hasil korelasi antara variabel produksi perikanan budidaya kolam $\left(\mathrm{X}_{8}\right)$ dengan luas area kolam usaha budidaya perikanan $\left(\mathrm{X}_{10}\right)$. Karena nilai 0.898 kurang dari 0.9 maka dinyatakan bahwa data penelitian tidak terdeteksi adanya multikolinieritas.

\subsection{Perbandingan Metode Optimasi pada Analisis Cluster}

Pada metode K-Means terdapat beberapa pertimbangan untuk menentukan jumlah cluster yang paling optimal. Pendekatan metode yang banyak digunakan adalah Metode Elbow, Metode Silhoutte, dan GAP Statistic. Hasil optimasi dari ketiga metode untuk Elbow dapat dilihat pada Gambar 4 berikut.
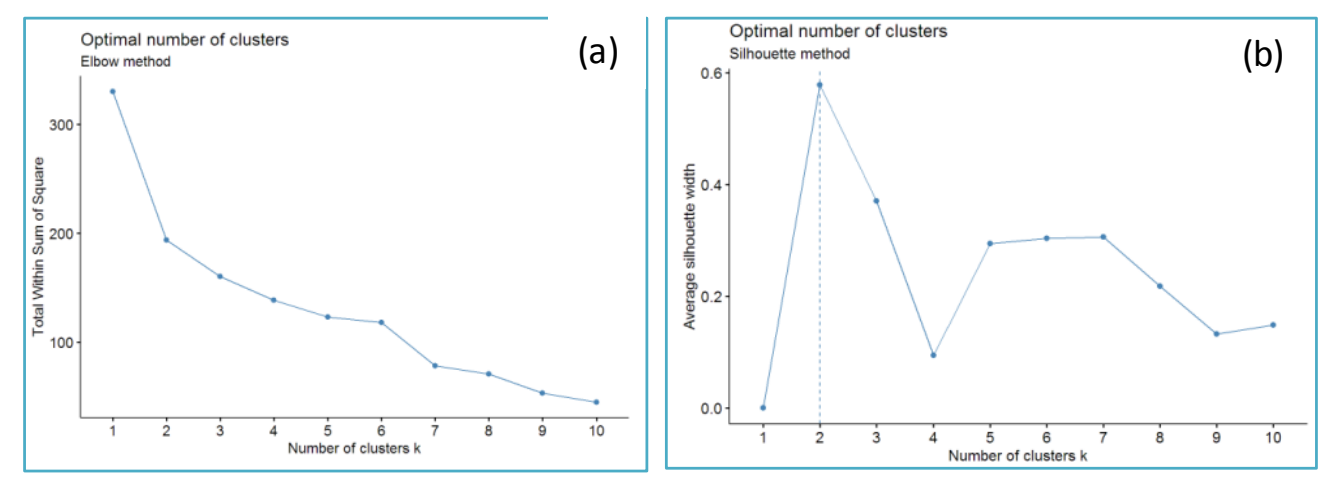


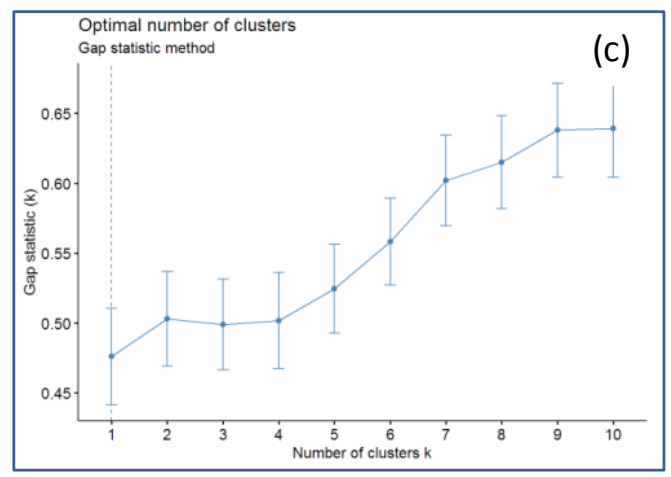

Gambar 2. (a) Grafik Method Elbow, (b) Grafik Metode Silhouette

(c) Grafik Metode GAP Statistic

Penentuan jumlah kelompok optimal dari metode elbow diperoleh dari nilai whitin Sum of Square. Grafik metode Elbow menunjukkan penurunan yang signifikan dan membentuk siku pada titik k=2. Sehingga dapat disimpulkan pada metode ini jumlah cluster optimal adalah 2. Metode kedua adalah metode Silhouette dapat dilihat pada Gambar 4 (b). Penentuan k optimal pada metode Silhouette dapat diketahui dengan melihat nilai average Silhouette, dengan asumsi semakin tinggi nilai average maka $\mathrm{k}$ tersebut semakin optimal. Pada gambar 4(c) tersebut menunjukkan bahwa nilai average Silhouette tertinggi berada pada k=2. Maka, dapat disimpulkan bahwa dengan menggunakan metode Silhouette diperoleh k optimalnya yaitu pada k=2. Metode terakhir untuk optimasi adalah metode GAP Statistic. Pada gambar 4 grafik GAP Statistic menunjukkan titik k berada pada k=1 yang merupakan jumlah optimal untuk membentuk cluster.

\subsection{Identifikasi Cluster dan Visualis asi Data}

Penentuan nama cluster dapat dilihat berdasarkan perbandingan nilai mean masing-masing variabel untuk setiap cluter. Pada penelitian ini, rata-rata sektor perikanan Indonesia menurut cluster seperti pada Tabel 4.

Tabel 4. Rata-Rata Sektor Perikanan Indonesia Tahun 2016

\begin{tabular}{|c|r|r|}
\hline \multirow{2}{*}{ Variabel } & \multicolumn{2}{|c|}{ Cluster } \\
\cline { 2 - 3 } & \multicolumn{1}{|c|}{$\mathbf{1}$} & \multicolumn{1}{c|}{$\mathbf{2}$} \\
\hline $\mathrm{X}_{1}$ & 23925.11 & 62072.13 \\
\hline $\mathrm{X}_{2}$ & 175922.04 & 325632.22 \\
\hline $\mathrm{X}_{3}$ & 4650.71 & 8053.21 \\
\hline $\mathrm{X}_{4}$ & 4088.78 & 35217.62 \\
\hline $\mathrm{X}_{5}$ & 13261.87 & 123363.46 \\
\hline $\mathrm{X}_{6}$ & 20271.32 & 148287.09 \\
\hline $\mathrm{X}_{7}$ & 29342.41 & 533048.85 \\
\hline $\mathrm{X}_{8}$ & 42755.07 & 251574.00 \\
\hline $\mathrm{X}_{9}$ & 11263.25 & 67004.15 \\
\hline $\mathrm{X}_{10}$ & 3782.84 & 13533.72 \\
\hline
\end{tabular}

Tabel 4 diatas dapat dilakukan profilisasi untuk setiap kolom yang terbentuk. Karakteristik pada cluster 1 yang memiliki anggota 30 provinsi memiliki nilai rata-rata lebih rendah dari cluster 2 . Sedangkan pada cluster 2 yang beranggota 4 provinsi merupakan daerah yang 
memiliki potensi sektor perikanan yang tinggi terdapat di provinsi Jawa Timur, Jawa Tengah dan Jawa Barat.

Untuk mengetahui anggota setiap cluster digunakan selisih jarak antar objek terhadap masing-masing centroid. Nilai dari centroid pertama dapat dipilih secara acak perhitungan jarak dilakukan dengan menggunakan persamaan jarak Euclidean pada persamaan 2, dimana objek dengan jarak terdekat dijadikan satu gerombol.

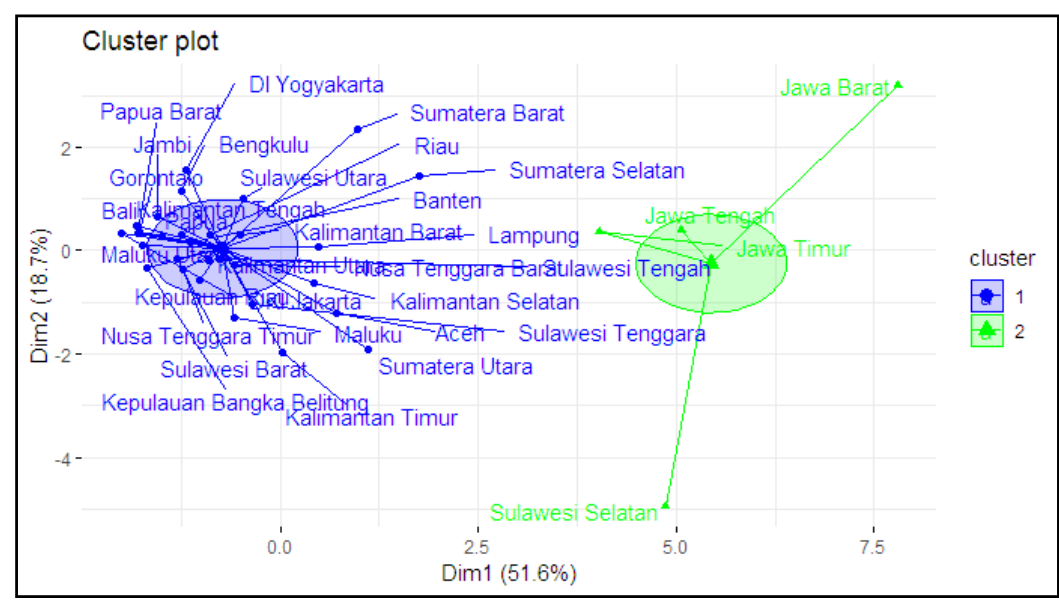

Gambar 5. Plot Pengelompokan Provinsi Indonesia

Gambar 5 diketahui bahwa dengan jumlah cluster optimal 2, terbentuk cluster 1 yang terdiri dari 30 provinsi, sedangakan Cluster 2 terdiri dari 4 provinsi. Pada bagian barat pulau Jawa terdapat suatu provinsi yaitu Banten, namun hal ini tidak menunjukkan adanya pencapaian yang positif pada sektor perikanan. Pada dasarnya tidak adanya kapasitas layanan seperti pelabuhan ikan yang sesuai untuk potensi wilayah yang ada menjadi salah satu alasan tidak tercapainya pemanfaatan zona penangkapan ikan (ZEEI).

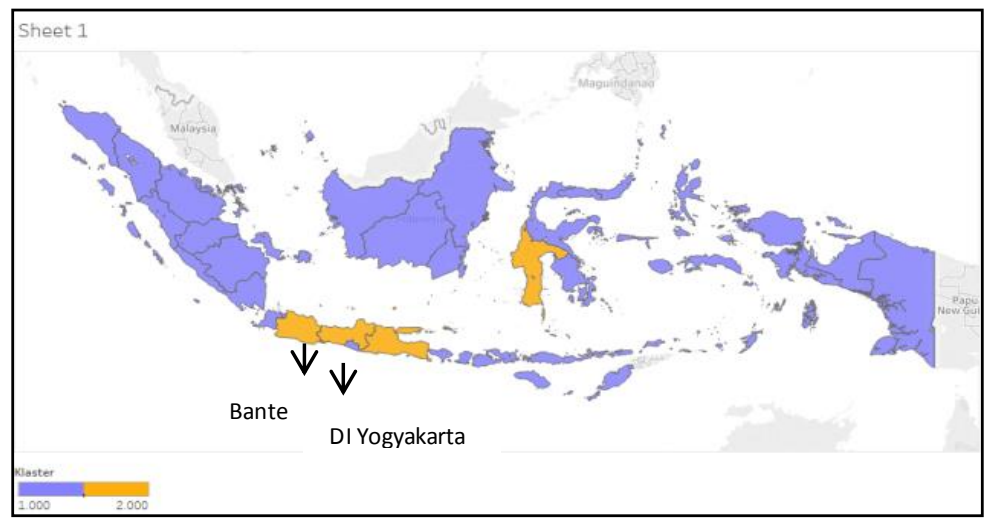

Gambar 6. Pengelompokan Provinsi Berdasarkan Analisis Cluster

Selain Banten, juga terdapat provinsi DI Yogyakarta yang masih tergolong rendah akan sektor perikanan, dilihat dari penduduknya sebagian besar bermata pencarian sebagai petani. Apabila ditinjau secara luas, dapat dikatakan tradisi menangkap ikan bagi masyarakat, dengan rata-rata trip untuk melaut per bulan hanya 20 hari. Begitu pula dengan pemabangunan sarana pelabuhan masih kurang mendukung.

\section{KESIMPULAN}

Indonesia memiliki 34 provinsi, berdasarkan data sektor perikanan di Jawa Timur memenuhi 9 variabel sektor perikananan. Hasil pengujian Kaiser Mayer Olkin menunjukkan 
nilai signifikansi 0.72 yang berarti sampel yang digunakan sudah cukup untuk dianalisis lebih lanjut dan memiliki nilai Korelasi Pearson tertinggi sebesar 0.898 kurang dari 0.9 menyatakan bebas multikolinearitas. Pada perbandingan optimasidari ketiga metode, diketahui cluster optimal dalam pembentukan cluster sebanyak 2 cluster dengan metode Elbow dan metode Silhouette.

Cluster pertama terdiri dari 30 provinsi, di antaranya Provinsi DI Yogyakarta, Banten, dan seluruh provinsi yang ada di pulau Sumatra, Pulau Kalimantan, Pulau Sulawesi, Nusa Tenggara, Maluku, serta Papua. Dimana cluster pertama ini tergolong sektor perikanan yang masih rendah, hal ini disebabkan infrastruktur masih belum memadai, pemanfaatan yang belum optimal, serta potensi sumber daya alam lainnya yang lebih memberikan kontribusi besar terhadap pendapatan daerah. Sedangkan cluster kedua terdiri dari 4 provinsi yaitu Jawa Timur, Tengah, dan Barat yang terletak di pulau Jawa sehingga secara geografis berhadapan dengan dua sisi lautan jawa pada bagian utara, dan samudra Hindia sehingga mendatangkan keuntungan yang besar dari produksi perikanan tangkap hasil laut.

\section{DAFTAR PUSTAKA}

Ediyanto, Mara M.N., Satyahadewi N., (2013), Pengklasifikasian Karakteristik Dengan Metode K-Means Cluster Analysis, Bulletin Ilmiah Matematika Statistika dan Terapannya, 2(2): 133-136.

FAO Fisheries Departement, (2006), State of world aquaculture 2006, FAO Fisheries Technical Paper, No.500. Rome, 134p.

Kementerian PPN, (2014), Kajian Strategi Pengelolaan Perikanan Berkelanjutan, Jakarta: Direktorat Kelautan dan Perikanan 2014.

Prayoga, A. \& Zain, I. (2015). Analisis Faktor dan Pengelompokan Kecamatan berdasarkan Indikator Mutu Pendidikan Jenjang Pendidikan Dasar di Kabupaten Sidoarjo. Surabaya: Institut Teknologi Sepuluh Nopember.

Supranto, J., (2004), Analisis Multivariat Arti dan Interpretasi, Jakarta: Rineka Cipta.

Yana, Mira Suci, dkk, (2018), Penerapan metode K-Means dalam pengelompokan wilayah menurut Intensitas Kejadian Becana Alam di Indonesia Tahun 2013-2018. Banda Aceh: Jurusan Statistika, FMIPA, Universitas Syiah Kuala. 